\title{
AOR
}

Selected Papers of \#AolR2021:

The 22nd Annual Conference of the

Association of Internet Researchers Virtual Event / 13-16 Oct 2021

\section{THE GEOPOLITICAL DYNAMICS OF GOOGLE}

\author{
ShinJoung Yeo \\ Queens College,City University of New York
}

US-based transnational corporation Alphabet (nee Google) controls search, a critical entry point to the Internet, dominating over $90 \%$ of the global search market (Johnson, 2021). Google's impressive capture of the Internet market seems to reaffirm a longestablished US-led global information order. However, this paper argues that the US position is far from secure, as the escalating tensions between geopolitical rivals is once again destabilizing the US-centric Internet.

As Dan Schiller (2014) points out, the extraterritorial internet is intertwined with the global political-economy and has turned into a vital site for profit-making and an axis of expansion for a transnationalizing capitalism. Thus, as the control over the internet is crucial for political economic power, the internet has become a battlefield between states, capitals and various social actors.

In the global arena, the two most contentious zones over the internet for the US center around the People's Republic of China (PRC), a relatively new and expansionary force within the global economy, and the European Union (EU), the longtime US ally as well as its global competitor and political counterweight historically. In China, where Google and other US tech companies have struggled to carve out a foothold in the largest market in the world, Chinese search engine Baidu dominates; meanwhile, due to Europe's dependence on US information systems, Google's global dominance has again provoked Europe's anxiety over losing control to the US as well as China over strategic emerging Internet sectors.

The western media persistently portrays the Chinese internet sector within the light of censorship and the great firewall; however, this rhetoric conceals the fact of China's deep integration into the global capitalist economy through its dynamic, home-grown and market-driven internet industry which is restructuring the political economy of transnational capitalism (Zhao, 2008; Schiller, 2011; Hong, 2017; Tang, 2019). The fear of China closing the gap over critical internet technologies, frustration regarding lack of access to the largest market in the world and its emergence as a new capitalist rival have spurred the US government to be fully engaged in order to safeguard its primacy

Suggested Citation (APA): Yeo, S. (2021, October). The Geopolitical Dynamics of Google. Paper presented at AolR 2021: The 22nd Annual Conference of the Association of Internet Researchers. Virtual Event: AolR. Retrieved from http://spir.aoir.org. 
over the most profitable Internet sector. To counter China, the current US government is taking a three-pronged approach - placing a range of sanctions against Chinese tech companies including tariffs, investment- and export controls; boosting their domestic internet sectors through science policy and increased funding; and flexing its political muscle to arrange new "digital alliances," pursuing a deal with the EU for a joint investment for critical and emerging internet sectors and forging an alliance with Japan, South Korea and Taiwan to isolate China. Meanwhile the EU is looking for a strategic balance between China - the EU's largest trading partner - and the US - its secondlargest - to serve its own interests and has asserted its power by writing new global rules and regulations for the Internet and has funded a European-based internet sector. At the same time, China is leaning once again on its policy of renewing investment in its domestic internet sectors to wean the country off its reliance on foreign technologies and urging Chinese companies to expand to overseas markets in emerging sectors such as $\mathrm{Al}$ and $5 \mathrm{G}$.

The Biden administration has signaled that the US is determined to maintain its power over the Internet by continuing to self-servingly position itself as a leader of "human rights" and "democracy;" however, this US project is not without mounting challenges. For decades, the internet sectors of the US and China have been increasingly integrated to the point where they are interdependent in sharing the transnational accumulation process. The US Chamber of Commerce has reported that a so-called "decoupling" between China and US would cost US $\$ 190$ billion dollars. US Treasury Secretary Janet Yellen hinted that the US needs to separate to a certain degree but warned of the danger of a complete decoupling from China's tech sectors and doubted whether US allies would side with the US and cut off China (Shalal, 2021).

Despite Biden's proclaimed battle for the utility of democracy, the question is not about which country or which company will transform the internet as a global public resource and deliver more democratic information provision. Rather, it is more about which capitalist state or which company will have the upper hand to shape the internet's profitable sites? Given the increasing transnational nature of global capitalism, to what extent will the US, EU, and China clash without destabilizing the shared project of a global capitalist economy? How and in what ways will these super economic powers collaborate to privilege transnational- as opposed to domestic capital and navigate domestic political and social interests?

Facing competition and political challenges, what is certain is that the US government, Google and the other major US tech companies will do everything to maintain the UScentric Internet industry through alliance and coercion. However, what is also certain is that the opposition from its rivals will also intensify. With new geopolitical pressure accompanying the changing power structure of transnational capitalism, the ground of the US-centric Internet is cracking and will continue to shift and quake. 


\section{References}

Hong, Y. (2017). Networking China: The Digital Transformation of the Chinese Economy. University of Illinois Press.

Johnson, J. (2021, March 12). Global market share of search engines 2010-2021. Statista. https://www.statista.com/statistics/216573/worldwide-market-share-ofsearch-engines/.

Schiller, D. (2011). Geopolitical-economic conflict and network infrastructures. Chinese Journal of Communication 1(1), 90-107.

Schiller, D. (2014). Digital depression: information technology and economic crisis. University of Illinois Press.

Shalal, A. (2021). Yellen says U.S. may decouple to some extent from China to protect security. Reuters. https://www.reuters.com/world/us/yellen-says-us-maydecouple-some-extent-china-protect-security-2021-06-16/.

Tang, M. (2019). From "bringing-in" to "going-out": transnationalizing China's Internet capital through state policies. Chinese Journal of Communication 13(1), 27-46.

Zhao, Y. (2008). Communication in China: Political Economy, Power, and Conflict. Lanham, MD: Rowman \& Littlefield. 